\title{
Federalismo e cidadania na imprensa republicana (1870-1889) ${ }^{1}$
}

\author{
Cláudia Maria Ribeiro Viscardi ${ }^{23}$
}

Trata-se de um estudo sobre a cultura política compartilhada pelos republicanos, no contexto da propaganda. Para esse fim, utilizamos como fontes principais o mais importante manifesto publicado pelo movimento no Rio de Janeiro - o manifesto de 1870 - e fizemos uma análise de periódicos republicanos que circulavam na província de Minas Gerais, com ênfase em um deles: O Movimento, que circulava por toda a província.

Palavras-chave: republicanismo, cultura política, imprensa.

\section{Federalism and citizenship in the republican press (1870-1889)}

This paper is about the political culture that was shared by republicans, in the context of the propaganda. We used as primary sources the most important manifesto published by the movement in Rio de Janeiro - the 1870's manifesto - and we analyzed, as well, the republican newspapers that circulated in the province of Minas Gerais, highlighting one of them: O Movimento, which was distributed all over the province.

Keywords: republicanism, political culture, press.

\footnotetext{
${ }^{1}$ Este trabalho é um dos resultados da pesquisa financiada pelo CNPq e pela Fapemig. Uma versão em inglês deste texto foi apresentada no Congress of the Latin American Studies Association, em Toronto, Canadá, em outubro de 2010.

${ }^{2}$ Artigo recebido em 26/3/2011 e aprovado em 20/9/2011.

${ }^{3}$ Professora-associada do Programa de Pós-Graduação em História da Universidade Federal de Juiz de Fora, doutora em História Social pela UFRJ, bolsista de produtividade do CNPq e pesquisadora do Programa do Pesquisador Mineiro (PPM) - Fapemig/MG.

E-mail: claudia.viscardi@uff.edu.br
} 


\section{Le fédéralisme et la citoyenneté dans la presse républicaine (1870-1889)}

Cette recherche traite de la culture politique partagée par les républicains dans le context de la propagande républicaine. À cette fin, nous avons utilisé comme source principale le plus important manifeste publié par le mouvement à Rio de Janeiro - le manifeste de 1870 - et avons fait une analyse des journaux républicains qui ont circulé dans la province de Minas Gerais, avec une emphase sur eux: O Movimento.

Mots-clés: républicanisme, culture politique, presse.

A inauguração do regime republicano brasileiro, ocorrida ao final de 1889, foi acompanhada pela implantação do federalismo e pelas discussões em torno da necessidade de se expandir a cidadania. O País vivenciava um período de modernização, que, segundo Bendix, é entendido como um conjunto de mudanças sociais e políticas que acompanham a industrialização. Ao longo desse processo, ocorrera a expansão da autoridade pública e da cidadania. O advento da cidadania se deu com a ruptura de relações paternalistas, resultante da proliferação dos protestos sociais. ${ }^{4}$

Ainda segundo o autor, no que tange à experiência europeia, o tradicional sistema paternalista fora rompido por duas revoluções: uma política (Revolução Francesa) e outra econômica (Revolução Industrial Inglesa). Embora as trajetórias de França e Inglaterra tenham sido mais exceções do que regras - mesmo no seio da própria Europa Ocidental -, as transformações ocorridas, de âmbito cultural e tecnológico, foram espalhadas gradualmente por grande parte das nações, por meio de variados mecanismos, mesmo entre aquelas que não haviam vivido revoluções com o impacto das citadas. ${ }^{5}$ Dessa forma, os apelos por cidadania surgiriam, também, em ambientes adversos, em locais onde as circunstâncias históricas não os teriam engendrado.

Esse foi o caso dos países que viveram tardiamente o desenvolvimento tecnológico. Para eles, requer-se uma compreensão mais específica de suas trajetórias, para que não sejam vistos como retardatários no cumprimento de etapas transitórias em direção a um tipo ideal de desenvolvimento, que nunca se repetirá da

\footnotetext{
${ }^{4}$ BENDIX, Reinhard. Construção nacional e cidadania. São Paulo: Edusp, 1996. p. 39.

${ }^{5}$ Id., p. 91, 104 e 324.
} 
mesma forma como se processou nas nações mais prósperas. Suas particularidades devem ser levadas em conta.

O Brasil se enquadra nessa categoria. Seu processo de modernização se deu sob a inspiração das experiências europeias de mudança, aliadas às suas mais consolidadas tradições. Portanto, entender a modernização brasileira implica não só vinculá-la ao contexto europeu ou norte-americano, mas igualmente levar em conta as suas próprias tradições.

Com base nas prerrogativas anunciadas, acredita-se que o processo de construção de cidadania, que ocorreu paralelamente à expansão do Estado Nacional no Brasil, deve ser analisado a partir de sua própria trajetória política, sem que as relações e os intercâmbios culturais com experiências prévias sejam descartados. Igualmente, não se acredita que o melhor caminho seja o marcado pelo tom evolucionista, ou seja, a partir da avaliação de sua distância ou proximidade em relação ao modelo francês, britânico ou mesmo estadunidense. Se assim o fosse, tal processo de modernização só poderia ser entendido pela lente da ausência: ausência de povo, ausência de riqueza, ausência de cidadania, de nação, entre outras.

Entende-se que o Brasil, ao final do século XIX, teve muitas de suas tradições abaladas pela introdução de duas mudanças específicas: a abolição e o regime republicano. Ambos os eventos propiciaram condições para que o processo de modernização tivesse início no País. A abolição viabilizou a construção da cidadania, e a República, implantada a partir da difusão e da consolidação dos princípios liberais, permitiu a expansão da autoridade pública, resultante da extensão dos direitos políticos.

É sabido que, quanto mais se amplia o número de direitos, mais aumenta a intervenção do Estado na sociedade. ${ }^{6}$ A partir da abolição e da introdução do regime republicano, foram formalmente sistematizados os instrumentos de ampliação das liberdades políticas, mantendo-se as liberdades civis já previstas pela Carta de 1822, com ligeiras modificações. E o federalismo permitiu a expansão e a descentralização da autoridade política. Acredita-se que essa combinação entre a ampliação de direitos políticos e a descentralização conferiu ao País os requisitos básicos para a sua modernização.

\footnotetext{
${ }^{6}$ QUIRINO, Célia G.; MONTES, Maria L. Constituições brasileiras e cidadania. São Paulo: Ática, 1987. p. 31 .
} 
Com base na perspectiva supraelencada, pretende-se estudar como se deu no País a convivência entre relações paternalistas, que remontavam às mais longínquas tradições políticas brasileiras, e os ideais de modernidade, que remetiam a valores como os de cidadania, democracia, liberdade, igualdade, entre outros, já consolidados em solo europeu. Com o estudo do republicanismo, pretende-se esboçar um pouco da cultura política republicana construída pelos principais atores políticos do período, tendo como foco a relação que propunham entre Estado e sociedade civil.

Procuraremos analisar os diferentes projetos de República propostos pelas principais lideranças que compunham a propaganda republicana, tendo como foco a expansão da autoridade pública - aumento do aparato institucional do Estado - e da cidadania - a proposição de canais de inter-relação entre autoridade e sociedade civil - no contexto da modernização brasileira. Faremos isso por meio da análise da imprensa republicana.

A partir da Bill of Rights - promulgada pelo parlamento britânico em 1689 e mais tarde retomada pelos Estados Unidos em sua Independência, e pela França no contexto da Revolução -, caberia ao Estado ser o responsável pela correção das desigualdades naturais entre os homens, garantindo, por meio das leis, princípios que assegurariam aos cidadãos os seus direitos. ${ }^{7}$ Influenciados pelas experiências francesa e estadunidense que resultaram em dois modelos distintos de República, os republicanos brasileiros tiveram de fazer algumas escolhas.

Além da preocupação dos mais proeminentes atores políticos na ocasião com a melhor forma de viabilizar institucionalmente o novo regime, a partir da observação das experiências históricas que lhes serviam de referência, pelo menos dois projetos teóricos podiam ser, a princípio, visualizados como pertinentes: o da tradição republicana que remontava a Maquiavel, cuja ênfase se encontra no poder da comunidade, ou seja, a coletividade é vista como portadora da virtude cívica, e o da tradição liberal, que ressaltava os direitos individuais e via no resguardo destes o caminho responsável pela inclusão do povo no projeto de nação que então se esboçava. ${ }^{8}$

\footnotetext{
${ }^{7}$ Id., p. 28.

${ }^{8}$ PUTNAM, Robert D. Comunidade e democracia: a experiência da Itália Moderna. 3. ed. Rio de Janeiro: FGV, 2002. p. 101.
} 
Com base em Richard Morse, ${ }^{9}$ pode-se afirmar que as tradições brasileiras apontavam para a ênfase na integração, herdeiras que eram do tomismo ibérico. Mas não se pode desconsiderar o peso que a experiência dos Estados Unidos exerceu sobre as tradições nacionais e o impacto que a cultura liberal anglo-saxã sempre teve sobre elas.

Diante desse leque de oportunidades, o que se torna perceptível de imediato é a predisposição dos republicanos para que as mudanças ocorressem exclusivamente no âmbito da política, privilegiando os debates e as decisões no Parlamento.

Ao mesmo tempo, ao se levar em conta as discussões travadas ao longo da propaganda republicana no Brasil, identifica-se a presença de duas correntes teóricas que serviam de horizonte para seus principais atores: a francesa e a norteamericana. ${ }^{10} \mathrm{O}$ modelo francês seria portador de duas vertentes: uma República em tom mais conservador, a positivista, e uma em tom mais radical, a jacobina. ${ }^{11}$ Segundo a historiografia já produzida sobre esse assunto, os mais proeminentes intelectuais brasileiros se filiariam a um desses modelos. Releva-se aqui o impacto exercido sobre o Brasil pela experiência dos Estados Unidos, sobretudo no que tange à proposta de adaptação do modelo francês a territórios de grandes dimensões, o que se deu por meio do federalismo.

No entanto, segundo as análises disponíveis, nenhum dos modelos propostos teria saído vitorioso. Construiu-se, assim, uma República que não chegava a ser uma ditadura militar (modelo positivista), não incluía o povo (modelo jacobino) e implantara um federalismo desigual (modelo norte-americano). A República no Brasil foi estudada a partir de suas distorções em relação a seus marcos fundadores originais.

O presente trabalho se propõe enfocar esse tema de forma diferenciada. A partir do pressuposto, anteriormente anunciado, de que o processo de modernização brasileira foi construído com base na permanência do paternalismo o qual foi paulatinamente influenciado pela emergência de ideários europeus e

\footnotetext{
${ }^{9}$ MORSE, Ricard. O espelho de próspero: culturas e ideias nas Américas. São Paulo: Cia. das Letras, 1988.

${ }^{10}$ MATTEUCCI, Nicola. República. In: BOBBIO, N. (Org.). Dicionário de política. Brasília: UNB, 1986. p. 1.109.

${ }^{11}$ CARVALHO, José M. A formação das almas: o imaginário da República no Brasil. São Paulo: Cia. das Letras, 1990. p. 22.
} 
estadunidenses, que anunciavam a necessidade de ruptura com tal modelo -, o presente texto se dispõe a analisar as propostas dos republicanos não como desvios ou distorções em relação aos marcos originais externos. Ou seja, pretende-se entender a lógica das proposições dos mais proeminentes atores a partir de suas próprias referências históricas, tanto no campo das culturas políticas por eles compartilhadas como no dos acontecimentos históricos vivenciados por aquela geração no período.

No que tange às culturas políticas, já existem significativas contribuições historiográficas que as vinculam à chamada geração de 1870. O positivismo, o liberalismo doutrinário e o evolucionismo eram as mais conhecidas e influentes culturas compartilhadas pelos pensadores brasileiros no período.

Segundo abordagens de Astor Diehl, nos meios acadêmicos proliferava o viés cientificista, com a divulgação das teorias de Darwin, Taine, Comte, Renan, entre outros. Essa geração inspirava-se em três correntes distintas: o ecletismo, o positivismo e o evolucionismo. Mas tais pensadores teriam confundido

[...] a originalidade da história do Brasil com as novidades teórico-metodológicas europeias. Essas formas não receberam um tratamento crítico; foram adaptadas nem sempre para a interpretação da realidade histórica, mas para criar uma história legitimadora de posições políticas, de grupos sociais ou do próprio Estado. ${ }^{12}$

A própria Monarquia brasileira, tentando diferenciar-se das demais Repúblicas latinas, incentivava uma aproximação com os modelos europeus de cientificidade, civilidade e intelectualidade. Em seu estudo sobre a questão racial no período, Schwarcz igualmente critica essa pressuposta cientificidade, porque, segundo a autora, os principais teóricos da nação tinham acesso apenas a manuais e obras difusas provindos da Europa, compilações que nem sempre mantinham a integridade dos originais. Não obstante, sentiam-se sábios, e nesse sentimento tinham o apoio do imperador, o qual via a si próprio como um cientista. ${ }^{13}$

Segundo a autora citada, o panorama intelectual brasileiro no final do século XIX havia se tornado mais diversificado em relação ao passado, na medida em

\footnotetext{
${ }^{12}$ DIEHL, Astor A. A cultura historiográfica brasileira: do IHGB aos anos 1930. Passo Fundo: EDIUPF, 1998. p. 94.

${ }^{13}$ SCHWARCZ, Lilia. O espetáculo das raças: cientistas, instituições e questão racial no Brasil, 1870-1930. São Paulo: Cia. das Letras, 1993. p. 31.
} 
que a Escola de Direito de São Paulo assumira uma vertente mais liberal e a Escola de Recife estivera mais próxima ao darwinismo social. ${ }^{14}$

Ambas as instituições haviam sido criadas em 1828, mas, cerca de 40 anos depois, se diferenciaram em termos teóricos. A de Recife, que tinha em Tobias Barreto seu teórico de maior expressão, era mais voltada para o estudo dos filósofos alemães e dos darwinistas sociais, e a de São Paulo voltava-se menos para as discussões filosóficas e atuava mais como formadora de quadros políticos para o País. ${ }^{15}$

Além desses trabalhos mais focados no pensamento político e cultural da geração de 1870, há igualmente uma gama de estudos sobre como se processou o movimento político da propaganda republicana, do qual faziam parte muitos desses intelectuais formados nesse ambiente.

Durante muitos anos, os estudos sobre a propaganda republicana no Brasil, além de pouco numerosos, eram regionalizados. Destacam-se trabalhos sobre o movimento republicano paulista, fluminense e rio-grandense. ${ }^{16}$ Muito embora o regime monárquico fosse centralizado, os historiadores que se voltaram para o estudo da fase final do regime, com o objetivo de estudar a origem do federalismo, tiveram uma tendência a abordar o tema sob uma perspectiva estadualizada, provavelmente impactados pelo que se sucedeu após 1889 .

Esse panorama começou a ser mudado recentemente, com a publicação de trabalhos que discutem o pensamento republicano nacional a partir de novos fundamentos, como a busca da vinculação do pensamento republicano às práticas e aos interesses políticos de seus principais protagonistas ${ }^{17}$ e às referências culturais populares existentes no período, as quais teriam fundamentado as teorias da geração de $1870 .{ }^{18}$ Como são ainda poucos os trabalhos, estudar o movi-

\footnotetext{
${ }^{14} I d$., p. 25.

${ }^{15}$ GRINBERG, Keila. Código Civil e cidadania. Rio de Janeiro: Zahar, 2001. p. 17-18.

${ }^{16}$ Para o caso paulista: CASALECCHI, José Ênio. O Partido Republicano paulista: 1889-1926. São Paulo: Brasiliense, 1987. Para o caso fluminense: FERREIRA, Marieta de M. (Org.). A República na velha província: oligarquias e crise no Estado do Rio de Janeiro (1889-1930). Rio de Janeiro: Rio Fundo, 1989. Para o rio-grandense: LOVE, Joseph. O regionalismo gaúcho. São Paulo: Perspectiva, 1975.

${ }^{17}$ ALONSO, Ângela. Ideias em movimento: a geração de 1870 na crise do Brasil-Império. Rio de Janeiro: Paz e Terra, 2002. p. 35.

${ }^{18}$ MELLO, Maria T. C. de. A República consentida: cultura democrática e científica no final do Império. Rio de Janeiro: FGV/Edur, 2007. p. 12.
} 
mento republicano sob uma perspectiva de âmbito nacional trata-se de um desafio ainda a ser vencido, para o qual queremos contribuir.

Dessa forma, o presente artigo se propõe a identificar, no material produzido pelos principais atores políticos envolvidos na propaganda, quais culturas políticas eram por eles compartilhadas. Inspirados pelos teóricos europeus e pelas experiências históricas republicanas conhecidas, que escolhas fizeram a partir das diferentes apropriações realizadas dos discursos disponíveis. Sabe-se que o movimento republicano era composto de variados grupos sociais: jovens militares, jornalistas, professores, médicos, cafeicultores e bacharéis que se dedicavam profissionalmente à política. Cada grupo possuía um conjunto de interesses diferenciados. Relacionar tais interesses a projetos distintos de República propicia uma releitura do período, contribuindo para novas respostas a questões que se encontram ainda em aberto. Assim, acredita-se na obtenção de resultados originais, não só por romper com uma visão assaz regionalizada do movimento republicano, como também por propor uma releitura do processo de construção das culturas políticas inauguradas ou reinventadas a partir do movimento republicano no Brasil.

Pensamos que a melhor forma de captar as culturas políticas compartilhadas pelos arquitetos da República brasileira é ter acesso aos consensos por eles produzidos, os quais geralmente se encontram em seus textos partidários ou em suas imprensas oficiais, ou seja, os jornais que funcionavam como órgãos oficiais dos partidos republicanos. Para os fins deste texto, em primeiro lugar, foi priorizada a análise do mais importante manifesto republicano, considerado como marco fundador do movimento propagandista; em segundo lugar, analisamos a imprensa republicana mineira, dando destaque a um dos mais importantes jornais republicanos da província, O Movimento, órgão do Partido Republicano Mineiro. Em ambos os conjuntos documentais estaremos atentos à consecução dos objetivos previamente anunciados.

\section{A República no manifesto de $1870^{19}$}

O manifesto republicano foi publicado pela primeira vez no jornal A República, em 3 de dezembro de 1870, com o fim de fundar um partido político republicano de âmbito nacional. De autoria desconhecida, foi assinado por 58 apoiadores.

${ }^{19} \mathrm{O}$ manifesto republicano de 1870. In: PESSOA, Reynaldo C. A ideia republicana no Brasil através dos documentos. São Paulo: Alfa-Ômega, 1973. p. 39-62. A partir deste momento, as referências ao 
É importante iniciar qualquer análise a partir de seus signatários. Das 58 assinaturas, 48 traziam a profissão dos signatários. Levando-se em consideração esse aspecto, temos o seguinte quadro:

\begin{tabular}{|l|c|c|}
\hline Profissão & Número & Percentual \\
\hline Advogados & 15 & 21,73 \\
\hline Médicos & 9 & 13,04 \\
\hline $\begin{array}{l}\text { Negociantes/Capitalistas } \\
\text { e Fazendeiros }\end{array}$ & 9 & 13,04 \\
\hline Políticos & 8 & 11,59 \\
\hline Jornalistas & 8 & 11,59 \\
\hline Engenheiros & 5 & 7,24 \\
\hline Servidores Públicos & 3 & 4,34 \\
\hline Professores & 2 & 2,89 \\
\hline Sem Informação & 10 & 14,49 \\
\hline
\end{tabular}

Como se pode notar, a grande maioria dos assinantes do manifesto pertencia à elite intelectual do Império, pois eles eram portadores dos raros títulos de nível superior então existentes no País. O setor produtivo estava também representado, muito embora em menor número que aqueles ligados ao setor de serviços. $\mathrm{O}$ grande número de advogados se explica não só por ser a formação em Direito uma das poucas oportunidades de construção de carreiras existentes no País, como também por nossa elite ter sido reconhecidamente composta por bacharéis, desde tempos imemoriais. ${ }^{20}$

Muito embora não houvesse uma carreira com formação superior em Jornalismo, muitos que se assim diziam possuíam formação em Direito ou eram autodidatas. Pertenciam, então, a uma minoria letrada, formadora de opinião.

Talvez seja por essa razão que o manifesto faça tanta alusão à existência de uma opinião pública favorável às propostas de mudança. Não há referência no texto a quem compunha essa opinião e a como ela se manifestava. Trata-se de um ente abstrato, como se pela expressão se entendesse a manifestação de um consenso nacional (p. 41 e 43).

manifesto virão entre parênteses, limitando-nos a indicar apenas suas páginas.

${ }^{20}$ A esse respeito, ver: VENÂNCIO FILHO, Alberto. Das arcadas ao bacharelismo: 150 anos de ensino jurídico no Brasil. 2. ed. São Paulo: Perspectiva, 1982; e ADORNO, Sérgio. Os aprendizes do poder: o bacharelismo liberal na política brasileira. Rio de Janeiro: Paz e Terra, 1988. 
Percebe-se, dessa forma, uma estratégia escolhida pelos autores do manifesto para se fazerem ouvidos: a de serem porta-vozes de uma aspiração nacional, de uma vontade coletiva, de uma cultura política compartilhada pela maioria da nação. No esforço de escapar do estigma de desordeiros ou revolucionários, utópicos ou outsiders, os signatários, militantes da causa republicana, iriam buscar na História nacional a legitimação de suas propostas, ao reforçarem seus vínculos com a tradição, e não com a modernidade. Em síntese, arvoravam-se à condição de portadores de uma legitimidade, porque podiam expressar uma opinião pública que remontava ao passado da nação.

Para esse fim, acabaram por fazer uma leitura muito enviesada dos acontecimentos que lhes antecederam. Para eles, a nação havia sido traída após a Independência em 1822. Apenas a forma havia sido mudada, com a substituição de um governante pelo outro, mas a essência do regime de dominação colonial fora mantida. Daí os republicanos verem a implantação da República como a real manifestação de libertação do Brasil do jugo português, e não os acontecimentos de 1822 (p. 42).

Para os republicanos, no momento da Independência, os interesses dinásticos precederam aos nacionais, e os ideais democráticos do povo brasileiro haviam sido desdenhados. A abdicação de D. Pedro I, em 7 de abril de 1831, foi lida como uma possibilidade de resgate da soberania nacional então perdida. O período regencial que sucedeu à abdicação era visto como a expressão fidedigna dos interesses mais democráticos da nação. Mas o fim do período regencial significou o fim dos sonhos dos brasileiros de constituírem uma nação livre. Segundo os novos intérpretes da História nacional, nossas instituições não eram suficientemente fortes para garantir o avanço da democracia. As mudanças legais realizadas acabaram por restringir as liberdades individuais, e a soberania do povo foi anulada (p. 44-45).

No texto, a nação é apresentada como estando em contínuo perigo, cabendo aos republicanos a missão de salvá-la. O panorama, em rigor, revelava decadência moral, perturbação econômica e desorganização administrativa. Apontavam-se, assim, dois caminhos para o futuro: ou a regeneração total ou o ocaso da liberdade. Esse fato era agravado pela ação do governante, que não tratava seus súditos como iguais, mas os discriminava segundo sua raça, seu grau intelectual e sua posição social (p. 41-42). 
Ainda em seu esforço de legitimação, o texto manifesta preocupação em conferir a seus autores credibilidade. Para isso, faz referências a diversas lideranças do Império que, de uma forma ou de outra, manifestavam suas críticas e insatisfações em relação ao regime em curso. Cita inúmeros políticos não vinculados ao movimento, mas que estavam descontentes com a Monarquia. Faz referências contínuas à imprensa não republicana e às suas críticas aos problemas do regime, apontados por ele como cruciais (p. 48-52). Tentava, a partir dessa estratégia, não se constituir em voz no deserto, mas portador de um projeto coletivamente aceito.

A base do manifesto é a crítica ao regime monárquico. E são tantas as críticas que ao final se tem a clara impressão de que o documento é muito pouco propositivo. $\mathrm{O}$ alvo mais visível é o Poder Moderador. O quarto poder é criticado pelos republicanos não pela sua adoção, mas pelo controle por ele exercido sobre os demais poderes. Com ele não havia representação nacional, liberdade individual e nem livre manifestação da vontade dos cidadãos. Ou seja, ele tornava nula a democracia. A nação havia se militarizado; o funcionalismo, se tornado dependente; e a soberania, ilusória (p. 46-47). Dessa forma, a crítica à concentração de poderes pelo monarca é repetida à exaustão. O poder exercido é avaliado como onipotente, perpétuo, acima da lei e da opinião (p. 41).

Muito embora a avaliação da conjuntura contenha referências ao caráter absoluto do exercício do poder pelo imperador, o que aparece no texto como maior alvo de condenação é o falseamento das instituições democráticas pelo poder constituído. Dessa maneira, antes de ser absoluto, despótico ou autoritário - adjetivos utilizados pelos signatários ao se referirem ao regime monárquico -, o Império era falso, corrupto e viciado. O que se condena com maior veemência eram os sofismas do exercício do poder, o falseamento das instituições democráticas, a proliferação da corrupção, os favoritismos pessoais, entre outras mazelas. Os republicanos se sentiam enganados e traídos pelo imperador, ao invés de se sentirem vitimados pela sua violência, condição que explicaria o epíteto "absolutista" por eles utilizado ao se referirem ao governante ou ao regime.

Dessa forma, as liberdades civis e políticas, previstas pela Constituição de 1824, eram vistas pelos signatários do manifesto como sofismas, na medida em que não funcionavam na prática (p. 42). A liberdade econômica era falseada por uma legislação restritiva; a liberdade de imprensa era contida pela censura dos 
funcionários do governo; a liberdade de associação era submetida à autorização do imperador; a liberdade de ensino era limitada pelo monopólio oficial das escolas; a liberdade individual era violada pelas prisões preventivas, pela imposição de recrutamento militar e pelo limitado funcionamento do instituto do habeas corpus. Essas seriam manifestações claras do falseamento das instituições democráticas anunciadas pela Carta de 1824 (p. 47).

Diante do quadro anunciado, principalmente por ser a Monarquia reconhecida como um governo de fins pacíficos, a estratégia de mudança passava menos pela revolução e mais pela reforma. O que se pretendia - e de fato é a única proposta concreta existente no manifesto - era a convocação de uma assembleia constituinte para que fosse dada ao País uma nova carta magna. Ou seja, o que se almejava era a realização de uma mudança institucional de cunho reformista, que se daria a partir de três prerrogativas: o convencimento pela palavra, a revolução moral e a implementação de mudanças nos procedimentos legais (p. 40 e 60).

Um texto deve ser lido também pelas suas ausências. Ao lê-las, percebemos um documento eivado de conservadorismo, que se manifesta pela defesa de muitas continuidades, muito embora fosse propositor de algumas mudanças. Tal conservadorismo manifesta-se pela omissão em relação a um dos problemas mais sérios com os quais a nação se defrontava no período, qual seja, o da questão servil. Para um movimento que dava os seus primeiros passos, portador de uma cultura política emergente, mas minoritária, convinha agregar o maior número de adeptos, abrindo mão, como estratégia de conquista desse espaço, de tocar em questões controversas que poderiam afastar do movimento uma parcela portadora de grande influência: a elite agrária. A abolição não era um consenso. A República, muito menos. Relacioná-las poderia levar tudo a perder. Daí justificar-se tão importante ausência.

Outro tema que aparece pouco no manifesto é o da laicização do Estado, reivindicada por um dinâmico setor do movimento republicano, o dos positivistas. Só há uma referência aos privilégios desfrutados por certo setor da Igreja, o que estaria causando prejuízos à liberdade de consciência (p. 47). A proposição da liberdade religiosa ou da separação entre Estado e Igreja, uma das bandeiras mais destacadas pelas bases do movimento, permaneceria distante do manifesto. Novamente entendemos essa omissão como uma estratégia cuidadosa dos repu- 
blicanos em não afastar do movimento os católicos e suas lideranças, importantes para a composição de uma opinião pública dominante.

Para além da convocação de uma nova assembleia constituinte há, porém, uma segunda proposição bastante concreta no manifesto: a implantação do federalismo à americana, mas que só aparece ao seu final. "No Brasil, antes ainda da ideia democrática, encarregou-se a natureza de estabelecer o princípio federativo" (p. 53). Com essa frase, os signatários do manifesto de 1870 alegavam que as condições geográficas do País apontavam para a conveniência da descentralização dos poderes. A centralização de uma nação, tão diversificada em sua geografia, foi vista como um elemento artificial imposto à nossa trajetória, já que desde os tempos coloniais a metrópole atuara por meio da implantação de poderes locais descentralizados. Mas o federalismo proposto era assaz limitado. Por federalismo se compreendia tão somente a autonomia provincial. Sua ausência implicava despotismo (p. 55).

Por fim, o lema "Somos da América e queremos ser americanos" (p. 60) associava a Monarquia à Europa e colocava o regime como uma excentricidade no continente americano. A permanência da Monarquia engendraria difíceis relações com nossos vizinhos, isolando o Brasil das demais nações coirmãs.

Do que agora foi visto, cabe refletir como era composta essa cultura política republicana. De onde vinham os conceitos utilizados pelos contemporâneos? No texto, encontramos uma única referência a um político ou intelectual estrangeiro. Trata-se de León Gambetta (p. 58), advogado e político francês, de fortes vinculações republicanas e de destacada participação na consolidação da III República Francesa. Sua reconhecida importância para a formulação de uma constituição republicana, mesmo em meio a uma maioria comprometida com a Monarquia, serviu de inspiração para os republicanos brasileiros, na medida em que era essa a via por eles almejada para o Brasil. Acreditavam que com o convencimento poderiam aprovar uma nova Constituição que mudaria a forma de governo. Daí o investimento contínuo na propaganda.

Além da referência à França republicana, dois conceitos são muito recorrentes no texto: soberania e democracia, que de certa forma se equivaliam. Para eles, democracia consistia na soberania popular, e a soberania era definida como a "coleção das vontades de um povo" (p. 59). Além disso, para os signatários do manifesto, democracia não poderia coexistir com Monarquia. De fato, 
os republicanos ou não conheciam ou omitiam a possibilidade de existir uma Monarquia constitucional à inglesa, como se vê por esta afirmação: “...o elemento monárquico não tem coexistência possível com o elemento democrático” (p. 59). O modelo constitucional almejado era do da III República Francesa, e não o da Monarquia parlamentar inglesa, certamente mais próximo do modelo brasileiro então em vigor.

A incompatibilidade entre Monarquia e democracia derivava do caráter hereditário da primeira, o qual se contrapunha à elegibilidade dos governantes, princípio inarredável da segunda: “...aceitar o sistema misto como um sistema racional e exequível é ultrapassar as raias do absurdo, porque é fazer preponderar o poder humano sobre o poder divino" (p. 57). Para eles, a Monarquia estaria necessariamente fundamentada no poder divino dos reis, por ser hereditária. Já na democracia, o poder fundamentava-se no povo. Pode-se, então, concluir, com base no texto do manifesto, que, para os seus autores, o oposto da Monarquia era a democracia, e não a República.

Daí se explica, talvez, o fato de não ser encontrada com frequência a palavra "República" no manifesto. Embora ele se intitule como "manifesto republicano" e tenha sido publicado em um jornal recém-criado que fazia alusão ao termo, a ideia republicana se faz ausente no texto. À exceção do título, o regime proposto só aparece ao final do manifesto, em sua conclusão. Por outro lado, a palavra "democracia" é muito frequente, o que nos induz a pensar que os autores do manifesto a vissem como sinônimo de República, ou que o regime republicano fosse o único capaz de garantir a democracia.

Starling e Lynch, como parte integrante do projeto Iberconceptos no Atlântico, foram buscar a origem dos termos "república e republicanismo" para os brasileiros no período anterior ao movimento republicano, qual seja, entre 1750 e $1850 .{ }^{21}$ Os autores identificam quatro fases distintas pelas quais os conceitos passaram. Na primeira fase, entre 1750 e 1792, o conceito de República esteve associado às abordagens clássicas romanas de Políbio e Cícero, ou seja, o de comunidade voltada para o bem comum ou de governo gerido por setores originários das camadas populares. Na segunda fase, que vai até a Revolta de 1817 em Pernambuco, a República, inspirada na Revolução Francesa, seria vista como a garantia

${ }^{21}$ STARLING, Heloísa; LYNCH, Edward C. República/republicanos. In: FERES JR., João (Org.). Léxico da história dos conceitos políticos do Brasil. Belo Horizonte: UFMG, 2009. p. 225-245. 
de um governo de iguais. A terceira fase do conceito estaria compreendida entre 1821 e 1834. Nesta fase, a República estaria associada à Revolução Constitucionalista do Porto e seria sinônimo de democracia ou de governo eletivo. Nesse período, República se associaria à experiência federalista norte-americana, mas os republicanos ainda estariam tímidos, escondendo-se sob a aceitação de uma Monarquia constitucional democrática. Na quarta fase, iniciada com a reforma constitucional de 1834, a República começou a ser vista como sinônimo de separatismo e, consequentemente de desordem. Os autores não avançam para a fase seguinte, ou seja, aquela em que a República retomava seus adeptos, passando a considerá-la como a salvação para todos os problemas da nação.

Pela análise que fizemos de seu manifesto fundador, o termo República, após 1870 , retomou o significado da terceira fase, ou seja, esteve associado à democracia e ao federalismo. No entanto, como a conjuntura havia mudado, os republicanos puderam expressar menos timidamente o seu projeto de alteração do regime.

O manifesto foi publicado na capital do Império e teve forte repercussão nas demais regiões do País. O Rio de Janeiro tornou-se o palco principal do movimento republicano. Analisar o impacto do movimento em uma região menos central e mais periférica ao movimento propicia avaliar o real impacto dessa cultura política emergente sobre o conjunto do País. Procederemos agora à análise de parte da imprensa republicana de Minas Gerais.

\section{A República na imprensa mineira}

Pretendemos agora fazer uma reflexão sobre os valores políticos defendidos pelos republicanos mineiros em seu mais importante veículo de comunicação no período, o jornal O Movimento, além de nos utilizarmos de outros jornais publicados na província, mas de forma menos central. Muito embora houvesse outros jornais republicanos circulando em Minas Gerais, O Movimento era o órgão oficial do Partido Republicano Mineiro e era impresso na capital da província, além de circular por vários rincões do interior. $\mathrm{O}$ veículo foi fundado às vésperas da instituição da República, tal como o partido político de cujas ideias era a expressão. Entre os jornais conhecidos era o que possuía a maior tiragem: cinco mil cópias. Funcionava bem como um instrumento de agregação dos republicanos mineiros e expressava o conjunto de uma cultura política republicana 
compartilhada entre os propagandistas brasileiros, na medida em que recebia a contribuição de articulistas de todo o País, envolvidos com a propaganda do novo regime.

Minas Gerais, a partir de 1850, tornara-se uma província majoritariamente cafeicultora. A maior parte de sua receita fiscal no período derivava do café, e tal realidade assim permaneceria até meados do século XX. Era também a província que reunia o maior número de escravos do Brasil, concentrados não só na atividade cafeicultora como também em uma dinâmica economia de mercado interno, responsável por abastecer de alimentos inúmeras outras províncias do Império. Centro político de incontestável importância, a província fornecia quadros políticos destacados para o regime monárquico. Em que pese esse fato, agregou em seu seio um movimento republicano relativamente forte e coeso, manifesto com a publicação de 24 jornais e a existência de 51 clubes republicanos e de 60 partidos políticos, sediados nos 113 municípios existentes em $1889 .{ }^{22}$

A historiografia brasileira sobre o advento da República teve de necessariamente relacionar a Proclamação da República à abolição da escravatura, dado que ambos os fenômenos foram contemporâneos. A despeito de terem sido processos distintos, muitos de seus militantes destacados compartilhavam as hostes de ambos os movimentos, em que pese o fato de terem existido abolicionistas monarquistas e republicanos escravistas.

Essa vinculação deu origem a uma das mais consolidadas teses explicativas da crescente adesão à República em Minas, a de que o projeto teria recebido forte sustentação política dos cafeicultores. Descontentes com a abolição da escravatura, esses empreendedores teriam responsabilizado a abolição pelo desmantelamento da estrutura produtiva do café. Segundo tais análises, a ausência de uma política consistente de reposição da mão de obra que abastecesse as promissoras fazendas teria conduzido centenas de fazendeiros em direção ao projeto republicano. ${ }^{23}$ Esse teria sido o caso de Minas Gerais, região produtora de café que recebeu imigrantes em número insuficiente para repor os trabalhadores libertos após a abolição e cuja economia sofreu, de fato, impacto negativo após a libertação dos escravos.

\footnotetext{
${ }^{22}$ Esses dados foram levantados em pesquisa realizada na imprensa republicana mineira.

${ }^{23}$ COSTA, Maria E. V. Da Monarquia à República: momentos decisivos. 5. ed. São Paulo: Brasiliense, 1991. p. 273.
} 
Conforme boa parte da historiografia assevera, os descontentes teriam aderido prontamente ao projeto republicano, ou por vingança, ou como uma forma de obter indenização do Império, com vistas à compensação das perdas provocadas pela abolição. O historiador Francisco de Assis Barbosa chega a associar a defesa do federalismo à estratégia de obtenção dessa indenização. ${ }^{24}$

Diferentemente do manifesto de 1870, a associação entre abolição e República era parte intrínseca do discurso dos republicanos mineiros, como se percebe pela citação a seguir, retirada de um pequeno jornal propagandista ao sul da província de Minas Gerais:

A democracia conquistou todos os espíritos, e à libertação dos negros seguiu-se fatalmente a libertação dos brancos. As datas se aproximam. A independência do Brasil não está ainda feita. Ipiranga é hoje uma mentira histórica. [...] A nação exige a sua independência política pela república federativa como impôs a libertação imediata dos escravizados. Essas duas redenções deveriam ter a mesma data, se em nosso país a vontade da Nação tivesse mais força e não se eclipsasse no choque de interesses pessoais... ${ }^{25}$

Notam-se nessa citação referências positivas à abolição. $\mathrm{O}$ fato de a notícia ter sido publicada uma semana após a aprovação da Lei Áurea explica a mudança de posicionamento em relação às omissões observadas no manifesto de 1870 anteriormente analisadas. Quando o jornal mineiro foi publicado, o fim da escravidão já era fato. Não havia perigo de o movimento republicano a ele relacionar-se. Nota-se, igualmente na citação, a reafirmação de um princípio anunciado antes pelo manifesto: o de que a República inauguraria, de fato, a independência do Brasil, e não 1822 .

Mas a abolição não seria vista sem críticas. Não raro apareciam referências no jornal $O$ Movimento à crise vivenciada pela lavoura em razão do impacto negativo que ela teria provocado sobre a economia regional. Reclames surgiam em relação aos erros cometidos pelo imperador ao decretar o fim do processo sem que medidas preparatórias tivessem sido implantadas antes de sua deflagração. No âmbito dos jornais republicanos analisados, percebe-se a manifestação do descontentamento dos fazendeiros de café em relação à falta de braços, à indis-

\footnotetext{
${ }^{24}$ BARBOSA, Francisco de A. (Org.). João Pinheiro: documentário sobre a sua vida. Belo Horizonte: APM, 1966. p. 99-101.

${ }^{25}$ Correio do Machado, Machado p. 1, 20 maio 1888.
} 
ponibilidade de créditos compensatórios, à ausência de uma política agressiva de atração de imigrantes, às altas tarifas alfandegárias cobradas do setor produtivo nacional, entre outras queixas. Esse amplo espaço oferecido pelos jornais republicanos aos fazendeiros descontentes constituía-se em estratégia de atração desses setores para a causa republicana.

Mas, como a abolição já havia sido decretada, os republicanos mineiros passaram a ter outra preocupação, qual seja, o destino dos milhares de ex-escravos. Para eles, o imperador não se preocupara com as milhões de almas, consideradas pela elite ilustrada do período como "bárbaras e embrutecidas". Jornais divulgavam e recomendavam que vários clubes republicanos se empenhassem na resolução desse problema, a partir da disseminação da educação para os libertos. Caberia aos clubes organizar aulas noturnas, ministradas por republicanos, com o fim de alfabetizar e complementar a educação básica desses setores.

Mas não só a educação dos libertos era objeto de preocupação dos propagandistas. Um dos mais destacados articulistas de um dos mais importantes jornais republicanos de Minas Gerais - O Colombo -, Júlio Barni - autor de um manual destinado aos militantes da nova forma de governo -, propunha uma nova educação política para todo o povo brasileiro com vistas a prepará-lo para a recepção da República:

Sem a instrução que esclarece os cidadãos, acerca de seus direitos, deveres e verdadeiros interesses, os votos são necessariamente cegos; e então o sufrágio universal, em lugar de ser a expressão da vontade de um povo livre, torna-se um instrumento do despotismo. ${ }^{26}$

Da mesma forma que o manifesto de 1870 apontava, o discurso republicano mineiro foi caracterizado pela manifestação de descontentamentos em relação à conjuntura monárquica vivida pelos seus principais atores. Tanto o imperador como toda a família real eram continuamente desqualificados pelos propagandistas. Não só eles eram alvo de críticas. O Conselho de Estado era duramente açodado pelos republicanos. A propaganda era construída com base em denúncias, que apontavam para o caos vivido pelo País e para a inoperância dos dirigentes na solução dos problemas mais prementes.

${ }^{26}$ O Colombo, Campanha, p. 3-4, 7 jul. 1878. 
A Monarquia era igualmente vista como uma excentricidade. "Pois uma instituição qualquer que não se adapte à índole e às condições sociológicas de um povo é um corpo estranho no organismo social que mais cedo ou mais tarde será por ele expelido." ${ }^{27}$ Tal excentricidade distanciava o Brasil do conjunto de países que compunham as Américas, restando ao País submeter-se às influências das antigas nações europeias, vistas pelo jornal como antiquadas. Entre as antigas nações não se enquadrava a França, que, ao lado dos Estados Unidos, constituíase em modelo de boa administração.

Essa admiração pelos federalistas americanos e pelos líderes mais proeminentes da Revolução Francesa manifestava-se por meio da adoção de pseudônimos pelos articulistas mineiros, os quais remontavam aos principais líderes de ambas as revoluções: a francesa e a estadunidense. Além do que, várias reportagens sobre esses movimentos eram publicadas nos jornais mineiros, todas com o fim de enaltecer os avanços por eles provocados. O grande feito dos franceses era objeto de comemoração das publicações de 14 de julho, data da Revolução. O exemplo a seguir explicita uma dessas comemorações:

A república brasileira saúda fraternalmente a sua irmã imorredoura, a patriótica e lendária França. [...] os fatos que temos notado da nossa história política nos demonstram cabalmente que a monarquia não se molda à índole brasileira, porque ela é corruptora, enfraquece os sentimentos, dilapida caracteres e o brasileiro patriótico como é aspira à independência, a altivez de espírito que só no governo republicano pode ter, porque é responsável perante o povo. ${ }^{28}$

Relembrando o mito salvacionista aludido pelo historiador francês Raoul Girardet, ${ }^{29}$ os republicanos anunciavam a República como uma panaceia capaz de salvar a nação de todas as suas mazelas:

A propaganda republicana vai fazendo tranquila e triunfalmente sua marcha vitoriosa através desta mísera nacionalidade que ela é chamada a galvanizar, rejuvenescendo-a. Por toda parte penetra, e é por todos recebida como a suprema esperança e a única salvação possível. ${ }^{30}$

\footnotetext{
${ }^{27}$ O Movimento, Ouro Preto, ano I, n. 2, 30 jan. 1889.

${ }^{28}$ Por Vaz de Lima: O Movimento, Ouro Preto, ano I, ed. 26, 14 jul. 1889.

${ }^{29}$ GIRARDET, Raoul. Mitos e mitologias políticas. São Paulo: Cia. das Letras, 1987. cap. 3.

${ }^{30} \mathrm{O}$ Colombo, Campanha, 1o fev. 1874.
} 
A construção de um algoz requeria a perfilhação de suas vítimas. Os jornais seriam pródigos na listagem delas. Os republicanos mineiros se diziam perseguidos pela Guarda Nacional e pelas polícias locais e caluniados injustamente. Para atraírem o interesse dos cafeicultores, empunhavam uma de suas mais importantes bandeiras: a da redução de impostos, colocando-se lado a lado daqueles que se sentiam extorquidos pela política fiscal do Império.

Os que pagam a festa, os que pagam a música, são justamente os que não dançam. A classe por excelência produtora é a lavoura, e o governo só se lembra dela para cobrança de impostos. [...] Entretanto, o que a lavoura tem deve ao sol e à chuva. [...] Quais são os donos da terra? O povo ou os parasitas? [...] quais os que devem corar? Nós ou vós? $?^{31}$

O discurso da vitimação completava-se com a associação dos republicanos à condição de cativos, tal como os escravos, mas desta feita cativos do imperador. A Monarquia aparecia comparada ao Antigo Regime francês, cujo tom absolutista era dado pelos abusos cometidos pelo governante no uso do Poder Moderador. O poeta Camilo de Campos expressava muito bem o sentimento ao qual nos referimos:

O Brasil suspira

Ai que dor

Sou cativo, bem cativo

Do imperador [...]

Os brasileiros suspiram

Ai que Dor

Somos cativos

Da filha do imperador [...]

Quando ficaremos

Ai que dor

Livres da família

Do imperador!....

As alusões de José Murilo de Carvalho ${ }^{33}$ ao resgate que o movimento republicano fez ao herói Tiradentes encontraram em Minas Gerais campo fértil de florescimento. Afinal, a província havia sido o principal palco de manifestação da

\footnotetext{
${ }^{31}$ O Movimento, Ouro Preto, ano I, n. 24, 3 jul. 1889.

${ }^{32}$ O Movimento, Ouro Preto, ano I, ed. 38, 16 out. 1889.

${ }^{33}$ CARVALHO, José M. Op. cit., cap. 2.
} 
luta pela Independência. Dessa forma, os republicanos mineiros se sentiam mais herdeiros dos inconfidentes do que os demais. A vitimação dos propagandistas republicanos encontrou respaldo na perseguição sofrida pelos inconfidentes. Viam na luta contra a Monarquia uma maneira de vingar a morte dos rebelados do século anterior, resgatando a justiça. A República apareceria como um novo evento fundador da nação. O poema a seguir explicita bem esse resgate. O poeta apresenta-se como o próprio Tiradentes:

[...] Cem anos fazem agora

Em que eu tentara a vitória

De libertar-te oh! Nação!

Fui preso, fui enforcado

Pela pátria esquartejado

Vendido por um irmão.

Hoje do alto do Empyreo

Olho o Brasil, me admiro,

Vendo tudo iluminado;

Se assim for, povo querido,

Por vós o trono abatido,

Tereis o mártir vingado. [... $]^{34}$

Municípios recém-criados na província, que pouca ou nenhuma contribuição tiveram para o movimento inconfidente, apropriavam-se dessa mesma memória para justificar a sua adesão à República. O manifesto republicano da cidade de Juiz de Fora, fundada somente em 1856, reproduzido em jornal da capital, era um exemplo claro de invenção da tradição. Assim se expressou:

Porque a história diz que Minas soube sempre ocupar a vanguarda nos grandes movimentos políticos de nossa pátria; porque o altivo e brioso povo mineiro, assim como fez dobrar por finados, ao aproximar-se-lhe uma vez o fundador do império, e apressou a queda do primeiro reinado, assim também é ele quem, hoje, neste país se bate com mais denodo e com mais admirável estratégia pela abolição do privilégio dinástico, pela reivindicação da soberania nacional, pela fundação dos Estados Unidos brasileiros. Sim, precisamente por ser a pátria de Felipe dos Santos, de Tiradentes e do venerando padre Camilo de Britto, a primogênita da democracia americana, no Brasil, é que um ministério de cortesãos tenta a todo transe convertê-la em sórdido balcão de sufrágios eleitorais, em vil mercado de consciências. ${ }^{35}$

\footnotetext{
${ }^{34}$ O Movimento, Ouro Preto, ano I, ed. 29, 6 ago. 1889.

${ }^{35}$ O Movimento, Ouro Preto, ano I, v. 32, 29 ago. 1889.
} 
Além do 14 de julho, os republicanos igualmente comemoravam o 21 de abril, ano da morte de Tiradentes. Tal como as procissões religiosas, essa data era comemorada com a recriação do martírio do líder, em seus últimos dias antes de ser esquartejado. As pedras que calçavam as ladeiras de Ouro Preto, então capital da província, conferiam ao quadro aspecto ainda mais lúgubre, ampliando o sofrimento dos inconfidentes, após terem sido traídos pelos que se opunham ao projeto de liberdade.

Com essa reconstrução do passado, os mineiros eram apresentados como se tivessem sido sempre republicanos e como se todas as suas lutas tivessem se dado com o fim de resgatar a liberdade. Por terem sido derrotados e vitimados outrora, os republicanos eram os novos inconfidentes a clamarem por justiça no presente.

Por meio das publicações republicanas mineiras, percebemos a construção de uma nova representação para a província. Minas é apresentado como palco de luta pela liberdade, mesmo que para isso tenha de usar a estratégia revolucionária. O discurso de ordenamento e pacificação, que sempre marcou as referências à província, era então transmutado em prol de uma luta contínua pela liberdade. Essa nova construção passava por uma reinterpretação de sua própria História, resgatando eventos antes ocultados pela memória, a exemplo da participação dos mineiros na Guerra dos Emboabas, em revoltas escravas e na Revolução Liberal de 1842. A luta dos republicanos era então respaldada por uma tradição mineira inventada, a qual realçava o conflito e a revolta como partes integrantes de sua trajetória.

Um dos mais importantes propagandistas republicanos em Minas Gerais foi Antônio Olinto dos Santos Pires. Em texto escrito anos após o movimento, fez questão de referenciar a participação mineira no conflito emboaba, no qual ressaltava o espírito beligerante dos mineiros:

[...] A terra parece que evapora tumultos e a água exala motins; o ouro tosse desaforos; destilam liberdades os ares; vomitam insolência as nuvens; influem desordens os astros; o clima é tumba da paz e berço da rebelião; a natureza anda inquieta consigo e amotinada lá por dentro, é como no inferno. Bramam graves trovões continuamente, de onde se precipita o raio ardente. $[. . .]^{36}$

${ }^{36}$ PIRES, Antônio O. dos S. A ideia republicana em Minas Gerais: sua evolução, organização definitiva do Partido Republicano. Revista do Arquivo Público Mineiro, Belo Horizonte: Imprensa Oficial de Minas Gerais, ano 21, fasc. 1, p. 19-20, 1927. 
Olinto usou um evento pregresso para justificar as razões da desobediência republicana. Tratava-se de um motim, mas um motim plenamente justificável, porque seu fim era a luta contra a tirania. Em prol da liberdade, qualquer ação violenta estaria plenamente justificada.

A partir do que foi posto, percebe-se uma diferença crucial em relação ao texto do manifesto de 1870 . O caráter reformista e conciliador havia sido transmutado em estratégia de amotinação. Tal mudança se explica pelo período em que os textos foram divulgados: o primeiro no início do movimento republicano, e o segundo ao final deste. Ao longo desses quase 20 anos, a propaganda mostrava-se frágil na consecução de seus objetivos. A via revolucionária passou, então, a ser apontada como um caminho possível e justificável, embora a propaganda jamais tenha sido abandonada.

O ideário político do movimento era também reforçado pelas festividades. Cada núcleo republicano existente na província organizava conferências públicas conhecidas como "meetings", para as quais era sempre convidada alguma liderança de destaque nacional para proferir uma palestra em prol da divulgação do ideal republicano. Tais ocasiões eram acompanhadas de inúmeras manifestações artísticas, como a música e o teatro.

Em geral, finda a conferência, os manifestantes saíam às ruas aos gritos, para saldar a República. Alguns cantavam o hino revolucionário francês, na língua original, outros entoavam hinos previamente elaborados para enaltecer o novo regime. As festas realizadas por ocasião da visita de Silva Jardim, um dos mais destacados próceres da República, a Ouro Preto foram assim descritas por um jornal republicano:

Uma grande multidão acompanhava-o ao hotel enquanto na praça se incorporavam os acadêmicos para realizarem a anunciada manifestação. Cerca de 500 moços com flambeaux e fogos desfilaram pela Rua Direita, em marcha cívica, ao som da Marselhesa, por entre aclamações entusiastas e, depois de terem percorrido as principais ruas de Ouro Preto, dirigiram-se ao Hotel Martinelli. [...] Foram levantados vivas ao partido republicano organizado, ao congresso e conselho federal, ao congresso provincial mineiro, ao Dr. Saldanha Marinho, a Quintino Bocayuva, Campos Salles, Aristides Lobo, Ubaldino do Amaral e ao Dr. Jardim, que foram freneticamente aplaudidos. ${ }^{37}$

\footnotetext{
${ }^{37}$ O Movimento, Ouro Preto, ano I, n. 15, 30 abr. 1889.
} 
Percebe-se um esforço em conferir aos líderes republicanos uma auréola de enaltecimento que os legitimaria como novos líderes da pátria. Preparava-se, assim, o terreno para a emergência de uma nova cultura política, a republicana. O golpe que daria fundação à nova forma de governo permitiria a consolidação dessa nova cultura, que se tornou, paulatinamente, dominante no País.

\section{Conclusões}

Ao longo deste artigo, procurou-se analisar de que forma os republicanos foram aos poucos edificando uma nova cultura política, que se configurava como uma alternativa às mazelas pelas quais se sentiam vitimados no contexto monárquico. Optamos pela análise de duas modalidades diferentes de documentos. A primeira trata-se do mais importante manifesto, carta fundadora do movimento republicano, que, embora publicado na Corte, destinava-se a unificar o discurso de um conjunto vasto de adeptos do novo regime.

O manifesto tinha caráter inaugural do movimento e expressava bem o patamar sobre o qual se edificariam, mais tarde, os pilares de uma nova alternativa política. Daí seu caráter ambíguo em relação às principais propostas que dividiam a Nação: a abolição e a laicização do Estado. Tais propostas, que convidavam o País a se inserir na modernidade liberal europeia, eram vistas ainda com desconfiança pelos atores republicanos, que compartilhavam desses valores e ao mesmo tempo carregavam dentro de si o peso das relações paternalistas que haviam fundamentado, durante séculos, a cultura política monárquica brasileira. Daí que o silêncio em relação a essas questões se explica não só pelo receio em não angariar apoio suficiente para a nova causa, mas, sobretudo, por serem muitos republicanos adeptos da escravidão e contrários a um Estado liberal inteiramente laico.

O silêncio sobre esses dois temas expressa bem o período de transição pelo qual passava o País. Como nos lembrou Bendix, citado anteriormente, toda transição para a modernidade implica a coexistência de valores ambíguos, alguns relativos ao passado que se quer deixar e outros afetos ao futuro que se quer anunciar.

A segunda modalidade de documentos analisados inclui jornais de outra província, do interior do Brasil, em um período posterior, ou seja, quase 20 anos após a fundação do movimento. Muito embora Minas Gerais fosse uma unidade política de grande importância para o Reino, o relativo distanciamento em relação à mobilização antimonárquica que se processava na Corte fazia com que os 
republicanos mineiros se posicionassem de forma um pouco diferenciada em relação ao quadro encontrado para o Rio de Janeiro.

Muito embora uma cultura política demande muito tempo para ser efetivamente transformada, o que foi possível notar, a partir da análise da imprensa mineira, foi a mudança de estratégia dos atores para a consecução de seus objetivos. Nota-se que a imprensa mineira não discutiu a abolição, porque já era este um fato dado, mas preocupou-se com o destino dos milhares de libertos, bem como com a situação econômica dos fazendeiros, que daquela mão de obra dependiam. Em relação à laicização, não se posicionou, até por ser a província muito católica. O que se destaca é a mudança de estratégia e dos usos do passado para que o projeto republicano fosse justificado. A estratégia reformista foi substituída por uma proposta revolucionária, em tom mais agressivo. Mesmo que para a mudança desse tom tivessem os mineiros de construir uma nova representação de sua História, que passou a ser narrada a partir de uma sucessão de conflitos e lutas cruentas. Os usos de imagens e símbolos do passado se deram a partir dos interesses imediatos de uma luta que se aprofundava: a disputa entre dois projetos distintos, entre duas culturas políticas em choque.

O projeto republicano saiu vencedor. Mas, até que a cultura política republicana se tornasse dominante, muitos anos teriam ainda de se passar. Implantado o regime, a primeira Constituição previu em um de seus artigos a realização de um plebiscito que escolheria entre uma das formas de governo: a Monarquia ou a República. A aprovação do artigo, que refletiu em fôlego final dos restauradores, ficou, porém, esquecida ao longo de muitos anos. Enquanto isso, o imaginário republicano era reforçado e consolidado por todo o País, em que pesem os problemas que o novo regime não conseguiria resolver. Mais de cem anos depois, o plebiscito previsto foi realizado. A derrota fragorosa dos monarquistas apontou para a realidade nua e crua da História: os vencedores haviam sido bemsucedidos em transformar uma cultura política emergente e minoritária em uma verdade incontestável. 
